Corporate Social

Responsibility and

Environmental Management

\title{
The effect of greenhouse gas (GHG) emissions on cost of debt: evidence from Canadian firms
}

\begin{tabular}{|r|l|}
\hline Journal: & Corporate Social Responsibility and Environmental Management \\
\hline Manuscript ID & CSR-17-0331.R1 \\
\hline Wiley - Manuscript type: & Research Article \\
\hline Keywords: & $\begin{array}{l}\text { GHG emissions, Climate change, Cost of debt, Environmental policy, } \\
\text { Canada }\end{array}$ \\
\hline
\end{tabular}

SCHOLARONEm

Manuscripts 


\title{
The effect of greenhouse gas (GHG) emissions on cost of debt: evidence from Canadian firms
}

\begin{abstract}
:
The aim of this paper is to investigate the relation between GHG emissions and cost of debt and to estimate the cost that lenders are imputing to GHG emissions. Data on GHG emissions were hand-collected from Carbon Disclosure Project (CDP) reports, while data on the cost of debt and other financial data were obtained from Bloomberg Professional database. Using a sample of Canadian firms, the results show that GHG emissions increase firms' cost of debt. In other words, for each additional tonne of GHG emissions, the cost of debt increases on average by $11-15 \%$. These results imply that creditors incorporate firms' GHG emissions into their lending decisions and they penalize the polluting firms. This could encourage firms to reduce and manage their GHG emissions since there is a cost associated with these emissions. This study is one of the first to examine the relationship between GHG emissions and the cost of debt.

Keywords: GHG emissions; Climate change; Cost of debt; Environmental policy; Canada.
\end{abstract}




\section{Introduction}

Greenhouse gas (GHG) emissions, also called carbon emissions, are increasing from year to year all over the globe (CDP, 2014; EPA, 2017). According to the Environmental Protection Agency (EPA) (2009), the increase in GHGs in the atmosphere is considered one of the key causes of the recent global warming. For example, in Canada, the increase in GHGs could result, by 2050, in an increase in temperatures of up to $5^{\circ} \mathrm{C}$ in the south and $9^{\circ} \mathrm{C}$ in the north, and an increase in precipitation; heavy rains could cause flooding and erosion problems (CDP, 2014).

Although environmental science research seems to confirm the adverse impacts of GHG emissions on climate change, there is little accounting and financial research has done on the financial effects of these emissions for firms.

Some researchers examined the effect of GHG emissions on firm's market value (Chapple et al., 2013; Matsumura et al., 2014; Saka and Oshika, 2014; Griffin et al., 2017) or on its cost of equity ${ }^{1}$ (Li et al., 2014; Kim et al., 2015). However, very few studies have examined the impact of GHG emissions on firm's cost of $\mathrm{debt}^{2}$. Moreover, most of the previous studies were focused on U.S. and Australian firms. The aim of this paper is to investigate the relation between GHG emissions and cost of debt and to estimate the cost that lenders are imputing to GHG emissions.

According to the Financial Times Lexicon", "the cost of debt is the effective rate that a company pays on its current loans, bonds and various other forms of debt. The measure provides an idea as to the overall rate being paid by the company to use debt financing".

\footnotetext{
${ }^{1}$ The cost of equity is the rate of return required by shareholders to compensate for the risk they undertake by investing their capital.

2 The cost of debt is a measure of the risk that lenders take into account when they lend money to a firm.

${ }^{3} \mathrm{http}: / /$ lexicon.ft.com/Term?term=cost-of-debt.
} 
A higher cost of debt means the company has poor credit and higher risk. A lower cost of debt implies the company has good credit and less risk.

This paper seeks to address this research gap and to contribute to the literature in several ways. First, I focus on Canadian firms, a sample not previously studied with regard to GHG emissions. Indeed, Canada is ranked 9th of the top 10 emissions producers, but is the top producer per capita, approximately 6 percent higher than the United States and 19 percent above the world average (See Figure 1) ${ }^{4}$. Second, I use data over a period of 4 years, from 2012 to 2015, compared to prior studies (Stanny and Ely, 2008; He et al., 2013; Chapple et al., 2013; Luo and Tang, 2014) that focus on a single year. Third, I use data on GHG emissions from Carbon disclosure project (CDP) reports compared to prior studies (Al-Tuwaijri et al., 2004; Hossain and Reaz, 2007; Clarkson et al., 2008; Kolk, 2008) that used firms' annual or sustainability reports. These CDP reports are considered more comprehensive, reliable and comparable sources of data than the other data sources as they provide few opportunities for managers to manipulate the data on GHG emissions (Luo et al., 2012; He et al., 2013; Luo and Tang, 2014; Lee et al., 2015). Fourth, I focus on one particular item of pollution that is GHG emissions. Indeed, GHG pollution differs from other types of chemical pollution in that it causes global warming. Laws and legislations are also different (Lash and Wellington, 2007; Luo and Tang, 2014). Fifth, I use in this study a more comprehensive measure of cost of debt calculated by Bloomberg, compared to previous studies (Orens et al., 2010; Lorca et al., 2011; Zhu, 2014; Jung et al., 2014; Li et al., 2014) that used weak measures based on interest rates only. Finally, I

\footnotetext{
${ }^{4}$ Other sources, such as the World Bank, show somewhat different data on total GHG emissions per capita. However, the World Bank data do not include GHG emissions from land use such as deforestation. In Figure 1, data on total GHG emissions per capita include land use change and forestry (LUCF), which gives a more complete picture of emissions and a better comparison between countries. The World Bank data can be viewed at: https://data.worldbank.org/indicator/EN.ATM.CO2E.PC?year_high_desc=true.
} 
include in my sample all activity sectors compared to other studies (Clarkson et al., 2008; Kim et al., 2015) that focused only on industrial and energy sectors.

The remainder of the present paper is organized as follows: Section 2 discusses the Carbon disclosure project (CDP), while Section 3 provides a brief overview of GHGrelated legislation in Canada. The review of relevant literature on GHG emissions is presented in section 4, leading to the development of our hypothesis in section 5. Section 6 then describes the methodology. The results are presented in Section 7 and Section 8 concludes.

\section{Carbon disclosure project (CDP)}

In the last years, firms have faced increasing pressure from various stakeholders, including investors, lenders, financial risk managers, insurance companies, and NGOs, to measure, monitor, manage and disclose their GHG emissions (Fornaro et al., 2009; Matsumura et al., 2014).

In order to focus firms on taking urgent action to build a truly sustainable economy by measuring and understanding their environmental impact, the Carbon disclosure project (CDP) was formed in the U.K. in 2000.

Since 2002, the CDP, an independent not-for-profit organization acting on behalf of over 800 institutional investors around the world, sends every year a questionnaire to the world's 6000 largest firms to ask information about their GHG emissions, risks, strategies and plans for managing and reducing these emissions (Wegener et al., 2013; Matsumura et al., 2014; Lee et al., 2015). Today, nearly a fifth of global GHG emissions are reported through CDP, giving it the largest database of primary corporate climate change 
information in the world (CDP, 2016). For example, in Canada, $60 \%$ of the top 200 largest firms listed on the Toronto Stock Exchange (S\&P/TSX) responded to the CDP questionnaire in 2014 (approximately 120 firms) (CDP, 2014).

According to many authors (Wegener et al., 2013; He et al., 2013; Luo and Tang, 2014; Matsumura et al., 2014; Lee et al., 2015), the evidence has shown that the standard CDP report allows for less flexibility for managers to manipulate the outcome, implying that the GHG information that it provides is useful for decision makers.

\section{Canadian GHG legislation}

Since the Kyoto Protocol, an international agreement linked to the 1992 United Nations Framework Convention on Climate Change (UNFCCC), the Canadian government has set ambitious targets to reduce GHG emissions at the national level. However, after a few years of implementation, the average emissions reduction progress of firms in Canada was behind schedule (CDP, 2014). Moreover, the Canadian government has decided in 2011 not to comply with the Kyoto Protocol, while many other countries simply chose to ignore it (RCGT, 2016).

More recently, in 2016, Canada has ratified the Paris Climate Change Agreement (RCGT, 2016). However, it is still very early to know the outcome of this agreement. In order to comply with this agreement, the federal government of Canada announced a new Pan-Canadian Framework on Clean Growth and Climate Change. This framework is the governmental plan to meet GHG emissions reduction targets. It includes a pan-Canadian approach to pricing carbon pollution, and measures to achieve reductions across all sectors of the economy. According to this framework, all Canadian provinces are 
expected, by 2018 , to have a GHG emissions regulatory mechanism such as a carbon tax or a cap-and-trade system (RCGT, 2016; Osler, 2016).

This implies higher fines and financial penalties for firms that fail to meet the GHG reduction target. Some authors call this a carbon risk (IPCC, 2007; Kim et al., 2015).

\section{Literature review}

Increased regulations on GHG emissions have generated a new field of research known as carbon accounting. In this setting, Matsumura et al. (2014) found a negative association between GHG emissions and market value of U.S. firms. Their results show that, on average, the market value decreases by $\$ 212,000$ for every additional thousand metric tons of GHG emissions.

In a similar study, Chapple et al. (2013) also report a negative association between a dichotomous measure of high- and low-GHG emissions intensity and the market value of Australian firms that are subject to new national regulations. Their results show that highGHG-intensive firms suffer a penalty of 6.57 percent of market capitalization compared to other low-GHG-intensive firms.

Using a sample of Japanese firms, Saka and Oshika (2014) also found that GHG emissions have a negative relation with market value of equity. More recently, Griffin et al. (2017) report that GHG emissions are negatively associated with stock price, and further, the negative relation is more pronounced for GHG-intensive firms. These marketvalue penalties associated with GHG emissions reflect the perceived relationship between GHG emissions and the firm's climate change related risk profile. This risk is generally 
driven by climate change regulations and the uncertainty surrounding compliance with these regulations (Epstein, 2008; Matsumura et al., 2014).

Other few studies have examined the relationship between GHG emissions and cost of equity, but the results are mixed. For instance, Kim et al. (2015) found that GHG emissions are positively related to the cost of equity of South Korean firms. However, Li et al. (2014) found little evidence that the GHG emissions affect the cost of equity of Australian companies.

\section{Hypothesis development}

Most of previous studies on cost of debt have been based on agency theory (Armstrong et al., 2010). In the context of GHG emissions, agency problems may arise when the visions or expectations of a lender and a borrower with regard to GHG-intensive projects are not aligned.

Indeed, GHG-intensive projects can be seen by lenders as risky because they usually involve the externalization of carbon pollution which is accompanied by the risk of having the implicit costs being explicitly shifted back to firms (Goss and Roberts, 2011). With increasing GHG-related legislations and regulations, a large portion of externalized costs could also be internalized (Jung et al., 2014).

The main agency problem is that, if GHG-intensive projects are successful, shareholders will benefit from most of the profits, but if unsuccessful, creditors will bear most of the costs. Moreover, even if GHG-intensive projects are successful, the creditors could face reputational risks associated with financing polluting projects. With the increasing GHGrelated legislations and regulations, GHG-intensive firms may also have to incur costs 
related to their GHG emissions through taxes or cap-and-trade systems, as well as the costs of reducing GHG emissions through the development of low-carbon technologies (Jung et al., 2014; Kim et al., 2015).

As lenders are exposed to carbon risk through their lending activities, they are expected to implement possible solutions such as the incorporation of carbon risk into their credit risk assessment and price protection through interest rates (Jung et al., 2014; Li et al., 2014). According to Matsumura et al. (2014), GHG emissions must be an essential element in analyzing a company's risk profile. Indeed, with increasing GHG-related legislations and regulations, financial institutions may face additional costs and risks when lending money to GHG-intensive firms (Wegener et al., 2013; Li et al. 2014).

If a firm is GHG emissions-intensive, then lenders are likely to charge the firm a higher risk premium ${ }^{5}$ (Li et al. 2014; Kim et al., 2015). The firm's default premium ${ }^{6}$ may also increase as credit rating agencies downgrade the debt of certain issuers in response to concerns about GHG emissions from GHG-intensive assets ( $\mathrm{Li}$ et al. 2014). For instance, Standard \& Poor's downgraded the debt of a large U.K. power-generating firm, Drax, owing in part to future business risks from new European emissions trading rules that are expected to increase carbon costs (Barley, 2009; Matsumura et al., 2014).

In this study, I expect that firms with relatively higher GHG emission levels have higher credit risk than firms with lower GHG emission levels. In other words, lenders are expected to impose a higher cost of debt on firms with higher GHG emissions.

\footnotetext{
${ }^{5}$ The risk premium is the additional interest lenders must charge borrowers to compensate any risks that may increase the likelihood of default.

${ }^{6}$ The default premium is the additional amount a borrower must pay to compensate the lender for assuming default risk.
} 
Consistent with these expectations, I propose the following hypothesis regarding the effect of GHG emissions on cost of debt:

Hypothesis: There is a positive relationship between GHG emissions and cost of debt.

\section{Methodology}

\section{Data and Sample selection}

Data on GHG emissions were hand-collected from CDP reports, while data on the cost of debt and other accounting and financial data were obtained from Bloomberg Professional database.

My initial sample is based on all Canadian firms listed on the Toronto Stock Exchange (S\&P/TSX) that responded to the CDP questionnaire from 2012 to 2015 (462 firm-year observations). From this initial sample, I eliminated firms that responded to the CDP questionnaire but chose not to publicly publish their GHG emissions (137 firm-year observations). Finally, I excluded firms with missing some financial data on Bloomberg Professional database (7 firm-year observations), which reduced my final sample to 318 firm-year observations (see Table 1).

[Insert Table 1 here]

In order to analyze the sample firms by sector, I opted for the CDP sector classification. This classification consists of grouping Canadian firms into nine different sectors. Table 2 presents the sample distribution by sector. The energy, materials, financials, industrials and consumer discretionary sectors made up the largest proportion of firms $(24.84 \%$, $19.50 \%, 18.55 \%, 11.63 \%$, and $10.38 \%$, respectively), whereas telecommunications 
services, utilities, IT and consumer staples sectors made up the smallest proportions (5.66 $\%, 4.72 \%, 2.52 \%$, and $2.20 \%$, respectively).

[Insert Table 2 here]

\section{Variables measurements}

Dependent variable: Cost of debt (CoD)

To measure the cost of debt I used the Bloomberg calculation method. Bloomberg (2013, p.18) describes his calculation method of cost of debt as follows: "Weighted average cost of debt for the security, calculated using government bond rates, a debt adjustment factor, and the proportions of short and long term debt to total debt. The debt adjustment factor represents the average yield above government bonds for a given rating class. The lower the rating, the higher the adjustment factor. The debt adjustment factor (AF) is only used when a company does not have a fair market curve (FMC). When a company does not have a credit rating, an assumed rate of 1.38 (the equivalent rate of a BBB+ Standard \& Poor's long term currency issuer rating) is used".

$\mathrm{CoD}=[[(\mathrm{SD} / \mathrm{TD}) *(\mathrm{CS} * \mathrm{AF})]+[(\mathrm{LD} / \mathrm{TD}) *(\mathrm{CL} * \mathrm{AF})]] *[1-\mathrm{TR}]$

Where:

$\mathrm{SD}=$ Short Term Debt (in millions of C\$)

$\mathrm{TD}=$ Total Debt (in millions of C\$)

CS $=$ Pre-Tax Cost of Short Term Debt (in \%)

$\mathrm{AF}=$ Debt Adjustment Factor (in \%)

$\mathrm{LD}=$ Long Term Debt (in millions of C\$)

$\mathrm{CL}=$ Pre-Tax Cost of Long Term Debt (in \%) 
$\mathrm{TR}=$ Effective Tax Rate (in \%)

For example, a cost of debt of $3.9 \%$ means that for every $1 \$$ raised from lenders, the company must pay its lenders almost $0.04 \$$ in return.

Independent variable: GHG emissions

Following prior studies that used CDP data (e.g. Wegener et al., 2013; Matsumura et al., 2014; Luo and Tang, 2014) I measured GHG emissions in two different ways: Total GHG emissions and GHG emissions intensity.

- Total GHG emissions (in metric tons) are measured as the total of direct emissions from GHG sources owned or controlled by the firm (Scope 1) and indirect emissions caused by the firm's consumption of electricity, heat or steam (Scope 2) (Matsumura et al., 2014).

- GHG emissions intensity is measured as the ratio of total GHG emissions to total sales. This intensity measure allows to control for the extreme difference that exist between sectors. Moreover, relative to total emissions, this intensity measure is more comparable across firms and between different reporting periods (Wegener et al., 2013; Luo and Tang, 2014; Kim et al., 2015).

\section{Empirical model}

To examine the relationship between GHG emissions and the cost of debt, the cost of debt $(\mathrm{CoD})$ is regressed on GHG emissions, along with control variables that are known to affect $\mathrm{CoD}$. The selection of control variables was guided by prior literature on cost of 
debt (Anderson et al., 2004; Orens et al., 2010; Qi et al., 2010; Goss and Roberts, 2011;

Lorca et al., 2011; Zhu, 2014).

$C o D_{i t}=\beta_{0}+\beta_{1} G H G_{i t}+\beta_{2} R O A_{i t}+\beta_{3} S I Z E_{i t}+\beta_{4} L E V_{i t}+\beta_{5} S I Z E_{i t}+\beta_{6} M / B_{i t}$

$+\beta_{7} V O L_{i t}+\sum S E C T+\sum Y E A R+\varepsilon_{i t}$

where

$C o D_{i t}=$ The cost of debt for firm $i$ in year $t$

$G H G_{i t}=$ Total GHG emissions or GHG emissions intensity of firm $i$ in year $t$

$R O A_{i t}=$ Return on assets measured as net income/total assets of firm $i$ at the end of year $t$

$S I Z E_{i t}=$ Size measured by logarithm of total assets of firm $i$ at the end of year $t$

$L E V_{i t}=$ Leverage measured as total debt/total assets of firm $i$ at the end of year $t$

$M / B_{i t}=$ Market to book value measured by the ratio between market value and book

value of equity of firm $i$ at the end of year $t$

$V O L_{i t}=$ Volatility measured by the standard deviation of the monthly stock returns of

firm $i$ in year $t$

$\sum S E C T=$ Sector fixed effect ${ }^{7}$

$\sum Y E A R=$ Year fixed effect ${ }^{8}$

$\varepsilon_{i t}=$ Error term

All data on control variables were extracted from Bloomberg Professional database.

\footnotetext{
${ }^{7}$ Because the sample firms belong to 9 sectors (consumer discretionary, consumer staples, energy, financials, industrials, IT, materials, telecommunications services and utilities), I included indicator variables to control for sector effects. Indeed, not all sectors are polluting and each sector may have specific regulations regarding GHG emissions.

${ }^{8}$ Because the study covers four-year period (2012-2015), I included indicator variables to control for time effects in order to control for variations in the data.
} 


\section{Results \\ Descriptive statistics}

Table 3 presents the descriptive statistics of the study's variables. The mean of cost of debt $(\mathrm{CoD})$ is $2.42 \%$ and ranges from $0 \%$ to $4.89 \%$, which is in line with prior studies (e.g. Goss and Roberts, 2011; Li et al., 2014). The mean of total GHG emissions is 2754995 metric tons, while the mean of GHG emission intensity is 618.928 . This figure means that our sample firms emit approximately 619 tonnes GHG per million dollars of sales on average, which also is in line with prior studies (e.g. Chapple et al., 2013; Kim et al., 2015; Griffin et al., 2017).

Regarding the control variable, the Table 3 shows that the mean value of ROA is 1.120 and ranges from -56.697 and 24.272 , showing that our sample contains performing and non-performing firms. The mean value of firm size (SIZE) proxy is 9.681 (equivalent of $\$ 527$ billion Canadian), indicating that our sample included relatively larger firms. The mean value of leverage (LEV), market-to-book (M/B) and volatility (VOL) are 0.241, 1.338 and 29.8, respectively, which are comparable with previous studies (e.g. Anderson, 2004; Qi et al., 2010; Goss and Roberts, 2011; Lorca et al., 2011; Zhu, 2014).

[Insert Table 3 here]

Table 4 reports the descriptive statistics by sector and ANOVA results between sectors. These results show that there is a significant difference at $1 \%$ level across sectors with respect to $\mathrm{GHG}$ emissions $(\mathrm{ANOVA}=19.798$ and 58.454) and the cost of debt (ANOVA $=4.610)$. Table 4 also shows that Utilities sector is ranked 1 st in terms of GHG emissions and cost of debt, followed by Energy, Materials and Industrials sectors.

[Insert Table 4 here] 


\section{Correlation analysis}

Table 5 presents Pearson correlation coefficients among the study's variables. As shown in this table, the correlations between the cost of debt $(\mathrm{CoD})$ and the two measures of GHG emissions (Total GHG emissions and GHG emissions intensity) are positively significant at 1 per cent level $(0.186$ and 0.182$)$. This finding supports the hypothesis according to which there is a positive relationship between GHG emissions and cost of debt. This implies that lenders incorporate firms' GHG emissions into their lending decisions. In other words, firms with high GHG emissions suffer from a higher cost of debt.

[Insert Table 5 here]

Regarding the control variables, Table 5 reports that the cost of debt (CoD) is negatively and significantly correlated with ROA, SIZE, and M/B, respectively, which in line with prior studies (e.g. Anderson et al., 2004; Orens et al., 2010; Goss and Roberts, 2011; Lorca et al., 2011; Zhu et al., 2014). However, the correlation between cost of debt (CoD) and LEV is positively significant, which also in accordance with previous studies (e.g. Orens et al., 2010; Goss and Roberts, 2011). Finally, the cost of debt (CoD) does not seem to be significantly correlated with volatility (VOL).

In sum, Table 5 shows that the correlations between explanatory variables are well below the critical value of 0.7 , thus indicating no evidence of multicollinearity. Moreover, Table 6 shows that Variance Inflation Factor (VIF) scores are all lower than 2.0, which confirm that there is no problem of multicollinearity.

[Insert Table 6 here] 


\section{Regression analysis}

Table 6 reports the results of an ordinary least squares (OLS) regressions of cost of debt on GHG emissions and control variables. In Model 1 I use the Total of GHG emissions as independent variable while the GHG emissions intensity is used as independent variable in Model 2.

As shown in Table 6, GHG emissions (Total GHG emissions and GHG emissions intensity) have a positive association with the cost of debt (CoD) after controlling for all of the variables known to affect the cost of $\operatorname{debt}(\beta=0.152 ; p<0.01$ and $\beta=0.111 ; p<0.10)$. The positive association means that higher GHG emissions contribute to the overall firm risk. Thus creditors require a higher risk premium to lend money to the firm, which increases its cost of debt.

This finding supports the hypothesis, implies that lenders incorporate firms' GHG emissions into their lending decisions. Accordingly firms with high GHG emissions levels confront higher financing costs when they raise capital from outside borrowers, which corroborates the results of Li et al. (2014).

Table 6 also shows that coefficients of GHG emissions range from 0.152 in Model 1 to 0.111 in Model 2 . The average of the coefficients is 0.131 , indicating that on average, for each additional tonne of GHG emissions, the cost of debt increases on average by 11-15 $\%$, which is considered as a financial penalty for the firm. This calculation allows firms to make optimal financing decisions that aim at reducing GHG emissions and cost of debt. A similar result was found by Kim et al. (2015) for the cost of equity.

These empirical findings imply that Canadian-listed firms with high GHG emissions have to reassess their borrowing abilities because lenders may require higher interest rates 
owing to the uncertainty concerning the impact of future emissions (Li et al., 2014). Moreover, if the company management has to consider an impairment test because of the GHG emissions legislation, it has to assess the risks that these emissions represent to the cost of debt according to International Accounting Standard (IAS) ${ }^{9}$ 36: Impairment of Assets.

Finally, Table 6 reports that the cost of debt $(\mathrm{CoD})$ is negatively and significantly associated with ROA, SIZE, M/B and VOL, respectively, which in line with prior studies (e.g. Anderson et al., 2004; Orens et al., 2010; Goss and Roberts, 2011; Li et al., 2014). These results imply that high performing and large firms with growth opportunities and volatile stocks benefit from lower debt costs. However, the association between CoD and LEV is positively significant, which also in accordance with previous studies (e.g. Anderson et al., 2004; Orens et al., 2010; Goss and Roberts, 2011). This implies that highly indebted firms suffer from a higher cost of debt.

\section{Conclusion}

This paper investigates the relation between GHG emissions and cost of debt and estimates the cost that lenders are imputing to GHG emissions.

Using a sample of 318 firm-year observations for Canadian firms from nine different sectors over the period 2012-2015, the results show that GHG emissions increase firms' cost of debt. In other words, for each additional tonne of GHG emissions, the cost of debt increases on average by $11-15 \%$. These results imply that creditors include the GHG emissions in the risk analysis of the firm and they penalize the polluting firms.

\footnotetext{
${ }^{9}$ Canadian-listed firms have mandatorily adopted the IAS/IFRS since 2011.
} 
This study is one of the first to directly investigate the effect of GHG emissions on the cost of debt in Canada and has important implications for markets participants, firms, environmental regulators, accounting profession, and academia.

For market participants, the results show that, although the Pan-Canadian Framework on Clean Growth and Climate change comes into effect only in 2018, the markets have already anticipated the effects of GHG emissions on the cost of debt. The findings suggest that lenders take into account extra-financial information on companies' environmental performance when assessing the creditworthiness of borrowers because they are aware of potential future risks that can arise for GHG-intensive firms (Kleimeier and Viehs, 2016). Therefore, lenders and other participants are advised to include GHG emissions as a risk factor when they make financing decisions.

For firms, the results could encourage firms to reduce and manage their GHG emissions since there is a cost associated with these emissions. Given that the findings show that firms may face significant risks of financing due to their emissions, firms involved in the Pan-Canadian Framework are recommended to assess their carbon price exposures in a timely manner and implement appropriate strategies to mitigate these GHG-related risks (Li et al., 2014). In this setting, the results could help firms to understand GHG emissions risks and include GHG emissions when assessing environmental performance. The findings could also encourage firms to adopt a more comprehensive strategy and actions to deal with climate change.

For environmental regulators, the findings show that the Pan-Canadian Framework will bring significant financial risks to the firms. It is suggested that regulators take these financial risks into account when they evaluate and update environmental legislation (Li 
et al., 2014). The results could also assist the regulators in the development of future policies regarding the disclosure of firm's GHG-related activities (Jung et al., 2014).

For accounting profession, the findings are important evidence for its view that GHG emissions will bring some financial risks to Canadian and international firms (Li et al., 2014). The recently introduced Pan-Canadian Framework is an impairment indicator and Canadian firms can apply IAS 36 to reassess their GHG emissions liabilities and assets, and thus, costs of debt.

Finally, for academia, the results corroborate the view that companies need an upgraded accounting system to meet the needs of a low-carbon economy (Ratnatunga et al., 2011). Accounting academics have to develop courses in carbon accounting, auditing and management to train students to practice in a green business environment (Luo and Tang, 2014).

This research is not without its limitations. First, the sample consists of S\&P/TSX Canadian firms who respond to the CDP questionnaire. This sample was selected on the basis of size measured by the market capitalization. The results may therefore apply only to large Canadian firms but not small ones. Second, restricting the analysis to publicly listed firms can also restrict the generalizability of results to these firms only. Third, the analysis is relied on CDP reports; thus, it is probably inappropriate to generalize the results to GHG emissions information disclosed through other communication channels. Finally, this research does not investigate the cost of GHG emissions control or GHG risk management that may be of interest to lenders and other market participants. The relationship between the cost of GHG emissions control and the cost of debt can be investigated in a further research. The effect of a firm's GHG risk management strategy 
can also be investigated in a further research as a mediating/moderating variable in the association between GHG emissions and cost of debt.

\section{References}

Al-Tuwaijri SA, Christensen TE, Hughes KE. 2004. The relations among environmental disclosure, environmental performance, and economic performance: a simultaneous equations approach. Accounting, Organizations and Society 29 (5/6): 447-471.

Anderson RC, Mansi SA, Reeb DM. 2004. Board characteristics, accounting report integrity and the cost of debt. Journal of Accounting and Economics 37: 315-342.

Armstrong CS, Guay WR, Weber JP. 2010. The role of information and financial reporting in corporate governance and debt contracting. Journal of Accounting and Economics 50: 179-234.

Barley R. 2009. Drax in power struggle with S\&P. Wall Street Journal, June 24.

Bloomberg (2013). What is weighted average cost of capital (WACC)?. Bloomberg Finance LP: 1-25.

Chapple L, Clarkson PM, Gold DL. 2013. The cost of carbon: Capital market effects of the proposed emission trading scheme (ETS). ABACUS: A Journal of Accounting, Finance and Business Studies 49 (1): 1-33.

Carbon Disclosure Project - CDP. 2016. GHG emissions dataset. CDP, U.K. https://www.cdp.net/en/investor/ghg-emissions-dataset (accessed May 20, 2018)

Carbon Disclosure Project - CDP. 2014. Driving climate resilience through carbon mitigation. CDP Canada 200 climate change report 2014. www.cdp.net. 
Clarkson PM, Li Y, Richardson GD, Vasvari FP. 2008. Revisiting the relation between environmental performance and environmental disclosure: an empirical analysis. Accounting, Organizations and Society 33 (4/5): 303-327.

CTV News. 2017. How U.S. policy could affect carbon emissions and where Canada stands. June 1. (accessed November 22, 2017)

Environmental Protection Agency - EPA. 2017. Climate change indicators: Greenhouse Gases. United States. (accessed November 22, 2017)

Environmental Protection Agency - EPA. 2009. Mandatory reporting of greenhouse gases. 74 FR 56260. Available at: http://www.gpo.gov/fdsys/pkg/FR-2009-1030/pdf/E9-23315.pdf

Epstein MJ. 2008. Making sustainability work: Best practices in managing and measuring corporate social, environmental and economic impacts. Berrett Koehler: San Francisco, CA.

Fornaro JM, Winkelman KA, Glodstein D. 2009. Accounting for emissions. Journal of Accountancy July 2009: 40-45.

Goss A, Roberts GS. 2011. The impact of corporate social responsibility and the cost of bank loans. Journal of Banking \& Finance 35: 1794-1810.

Griffin PA, Lont DH, Sun EY. 2017. The relevance to investors of greenhouse gas emission disclosures. Contemporary Accounting Research 34 (2): 1265-1297.

He Y, Tang Q, Wang K. 2013. Carbon disclosure, carbon performance, and cost of capital. China Journal of Accounting Studies 1 (3\&4): 190-220. 
Hossain M, Reaz M. 2007. The determinants and characteristics of voluntary disclosure by Indian banking companies. Corporate Social Responsibility and Environmental Management 14 (5): 274-288.

The Intergovernmental Panel on Climate Change - IPCC. 2007. Climate change 2007: Impacts, adaptation and vulnerability. Working group II. The $4^{\text {th }}$ assessment report. Cambridge University Press. Available at: https://www.ipcc.ch/pdf/assessmentreport/ar4/wg2/ar4_wg2 full_report.pdf

Jung J, Herbohn K, Clarkson P. 2014. The impact of a firm's carbon risk profile on the cost of debt capital: Evidence from Australian firms. Working paper. UQ Business School, The University of Queensland.

Kim YB, An HT, Kim JD. 2015. The effect of carbon risk on the cost of equity capital. Journal of Cleaner Production 93: 279-287.

Kolk A. 2008. Sustainability, accountability and corporate governance: exploring multinationals' reporting practices. Business Strategy and the Environment 17 (1): 115.

Lash J, Wellington F. 2007. Competitive advantage on a warming planet. Harvard Business Review 85 (3): 94-102.

Lee SY, Park YS, Klassen RD. 2015. Market responses to firms' voluntary climate change information disclosure and carbon communication. Corporate Social Responsibility and Environmental Management 22: 1-12.

Li Y, Eddie I, Liu J. 2014. Carbon emissions and the cost of capital: Australian evidence. Review of Accounting and Finance 13 (4): 400-420. 
Lorca C, Sanchez-Ballesta JP, Garcia-Meca E. 2011. Board effectiveness and cost of debt. Journal of Business Ethics 100: 613-631.

Luo L, Lan YC, Tang Q. 2012. Corporate incentives to disclose carbon information: evidence from the CDP global 500 report. Journal of International Financial Management \& Accounting 23 (2): 93-120.

Luo L, Tang Q. 2014. Does voluntary carbon disclosure reflect underlying carbon performance?. Journal of Contemporary Accounting \& Economics 10: 191-205.

Matsumura EM, Prakash R, Vera-Munoz SC. 2014. Firm-value effects of carbon emissions and carbon disclosures. The Accounting Review 89 (2): 695-724.

Orens R, Aerts W, Cormier D. 2010. Web-based non-financial disclosure and cost of finance. Journal of Business Finance \& Accounting 37 (9\&10): 1057-1093.

Osler. 2016. Canadian government carbon and greenhouse gas legislation. Canada. (accessed November 22, 2017)

Qi Y, Roth L, Wald JK. 2010. Political rights and the cost of debt. Journal of Financial Economics 95 (2): 202-226.

Ratnatunga J, Jones S, Balachandran KR. 2011. The valuation and reporting of organizational capability in carbon emissions management. Accounting Horizons 25 (1): 127-147.

Raymond Chabot Grant Thornton - RCGT. 2016. GHG emission reduction strategies, running the gamut from opportunism, to enthusiasm to clear-headedness. December 5, 2016. (accessed November 22, 2017)

Saka C, Oshika T. 2014. Disclosure effects, carbon emissions and corporate value. Sustainability Accounting, Management and Policy Journal 5 (1): 22-45. 
Stanny E, Ely K. 2008. Corporate environmental disclosures about the effects of climate change. Corporate Social Responsibility and Environmental Management 15 (6): 338348.

Wegener M, Elayan FA, Felton S, Li J. 2013. Factors influencing corporate environmental disclosures. Accounting Perspectives 12 (1): 53-73.

World Resources Institute. 2017. 6 Graphs explain the world's top 10 emitters. Washington, DC. USA. (accessed November 22, 2017)

Zhu F. 2014. Corporate governance and the cost of capital: An international study. International Review of Finance 14 (3): 393-429. 
Tables and Appendix

Table 1: Sample selection process

\begin{tabular}{|l|c|c|c|c|c|}
\hline \multicolumn{1}{|c|}{ Sample } & $\mathbf{2 0 1 2}$ & $\mathbf{2 0 1 3}$ & $\mathbf{2 0 1 4}$ & $\mathbf{2 0 1 5}$ & $\begin{array}{c}\text { Firm-year } \\
\text { observations }\end{array}$ \\
\hline $\begin{array}{l}\text { Initial sample: All S\&P/TSX } \\
\text { Canadian firms responding to } \\
\text { the CDP questionnaire }\end{array}$ & 105 & 116 & 119 & 122 & 462 \\
\hline $\begin{array}{l}\text { (-) firms that responded to the } \\
\text { CDP questionnaire but chose } \\
\text { not to publicly publish their } \\
\text { GHG emissions }\end{array}$ & 30 & 36 & 33 & 38 & 137 \\
\hline $\begin{array}{l}\text { (-) firms with missing some } \\
\text { financial data on Bloomberg } \\
\text { Professional database }\end{array}$ & 1 & 1 & 2 & 3 & 7 \\
\hline = Final sample & 74 & 79 & 84 & 81 & $\mathbf{3 1 8}$ \\
\hline
\end{tabular}

Table 2: Sample distribution by sector

\begin{tabular}{|l|c|c|}
\hline Sector* & $\begin{array}{c}\text { Firm-year } \\
\text { observations }\end{array}$ & $\mathbf{\%}$ \\
\hline Consumer discretionary & 33 & 10.38 \\
\hline Consumer staples & 7 & 2.20 \\
\hline Energy & 79 & 24.84 \\
\hline Financials & 59 & 18.55 \\
\hline Industrials & 37 & 11.63 \\
\hline Information technology (IT) & 8 & 2.52 \\
\hline Materials & 62 & 19.50 \\
\hline Telecommunications services & 18 & 5.66 \\
\hline Utilities & 15 & 4.72 \\
\hline & 318 & 100 \\
\hline
\end{tabular}

Notes: *CDP sector classification. 
Table 3: Descriptive statistics

\begin{tabular}{|l|c|c|c|c|c|}
\hline \multicolumn{1}{|c|}{ Variables } & Mean & Median & S.D. & Minimum & Maximum \\
\hline CoD (in \%) & 2.42 & 2.41 & 0.926 & 0.00 & 4.89 \\
\hline $\begin{array}{l}\text { Total GHG } \\
\text { emissions } \\
\text { (in metric tons) }\end{array}$ & 2754995 & 391898 & 5255.218 & 10 & 35072724 \\
\hline $\begin{array}{l}\text { GHG emissions } \\
\text { intensity (in \%) }\end{array}$ & 618.928 & 151.121 & 17.245 & 0.016 & 15470.985 \\
\hline ROA (in \%) & 1.120 & 2.155 & 8.337 & -56.697 & 24.272 \\
\hline SIZE (in log) & 9.681 & 9.399 & 1.723 & 6.198 & 18.773 \\
\hline $\begin{array}{l}\text { Total assets } \\
\text { (in millions of }\end{array}$ & 527529 & 12072 & 7970.921 & 491 & 142181296 \\
C\$) & & & & & \\
\hline LEV (in \%) & 0.241 & 0.229 & 0.144 & 0.000 & 0.689 \\
\hline M/B (in \%) & 1.338 & 1.209 & 0.516 & 0.616 & 4.332 \\
\hline VOL (in S.D.) & 29.800 & 22.136 & 20.229 & 5.909 & 118.649 \\
\hline
\end{tabular}

Notes: $\mathrm{N}=318$ firms. Please see Appendix for variable definitions.

Table 4: Descriptive statistics by sector and ANOVA

\begin{tabular}{|l|c|c|c|c|c|c|}
\hline \multirow{2}{*}{ Sector* } & \multicolumn{2}{|c|}{$\begin{array}{c}\text { Total GHG } \\
\text { emissions } \\
\text { (in metric tons) }\end{array}$} & \multicolumn{2}{c|}{$\begin{array}{c}\text { GHG emissions } \\
\text { intensity } \\
\text { (in \%) }\end{array}$} & \multicolumn{2}{c|}{$\begin{array}{c}\text { Cost of debt } \\
\text { (in \%) }\end{array}$} \\
\cline { 2 - 7 } & Mean & Rank & Mean & Rank & Mean & Rank \\
\hline Consumer discretionary & 702576 & 5 & 17.618 & 9 & 2.26 & 6 \\
\hline Consumer staples & 437130 & 6 & 31.598 & 7 & 2.21 & 7 \\
\hline Energy & 5490612 & 2 & 706.610 & 2 & 2.45 & 4 \\
\hline Financials & 138091 & 8 & 46.856 & 6 & 2.05 & 8 \\
\hline Industrials & 1676521 & 4 & 301.973 & 4 & 2.40 & 5 \\
\hline Information technology & 129675 & 9 & 31.485 & 8 & 1.67 & 9 \\
\hline Materials & 2365548 & 3 & 441.464 & 3 & 2.75 & 2 \\
\hline Telecommunications services & 192510 & 7 & 60.516 & 5 & 2.48 & 3 \\
\hline Utilities & 12982660 & 1 & 6502.991 & 1 & 3.16 & 1 \\
\hline \multicolumn{1}{|c|}{ ANOVA } & $19.798^{* * *}$ & & $58.454^{* * *}$ & & $4.610^{* * *}$ & \\
\hline & & & & & & \\
\hline
\end{tabular}

Notes: *CDP sector classification. ${ }^{* * *}$ Significant at 1 per cent level. 
Table 5: Correlation matrix

\begin{tabular}{|l|l|l|l|l|l|l|l|l|}
\hline Variables & CoD & $\begin{array}{l}\text { Total GHG } \\
\text { emissions }\end{array}$ & $\begin{array}{l}\text { GHG emissions } \\
\text { intensity }\end{array}$ & ROA & SIZE & LEV & M/B & VOL \\
\hline CoD & 1 & & & & & & \\
\hline $\begin{array}{l}\text { Total GHG } \\
\text { emissions }\end{array}$ & $0.186^{* * *}$ & 1 & & & & & \\
\hline $\begin{array}{l}\text { GHG emissions } \\
\text { intensity }\end{array}$ & $0.182^{* * *}$ & $0.699^{* * *}$ & 1 & & & & \\
\hline ROA & $-0.274^{* * *}$ & 0.013 & -0.060 & 1 & & & \\
\hline SIZE & $-0.104^{*}$ & $0.148^{* * *}$ & $-0.111^{* *}$ & 0.055 & 1 & & \\
\hline LEV & $0.195^{* * *}$ & $0.194^{* * *}$ & $0.233^{* * *}$ & -0.003 & $-0.187^{* * *}$ & 1 & \\
\hline M/B & $-0.155^{* * *}$ & -0.051 & $-0.102^{*}$ & $0.446^{* * *}$ & $-0.293^{* * *}$ & $0.138^{* *}$ & 1 & \\
\hline VOL & -0.041 & 0.004 & 0.058 & $-0.436^{* * *}$ & $-0.284^{* * *}$ & -0.017 & $-0.278^{* * *}$ & 1 \\
\hline
\end{tabular}

Notes: $\mathrm{N}=318$ firms. Please see Appendix for variable definitions. $* * *, * * *$ Significant at 1, 5 and 10 per cent level, respectively. 
Table 6: Regression analysis

\begin{tabular}{|c|c|c|c|c|c|c|}
\hline \multicolumn{7}{|c|}{ Dependent variable: Cost of debt (CoD) } \\
\hline \multirow[t]{2}{*}{ Variables } & \multicolumn{3}{|c|}{ Model 1} & \multicolumn{3}{|c|}{ Model 2} \\
\hline & $B$ & $t$ & VIF & $\boldsymbol{B}$ & $t$ & VIF \\
\hline Intercept & N/A & $7.131 * * *$ & N/A & N/A & $7.141 * * *$ & $\mathrm{~N} / \mathrm{A}$ \\
\hline $\begin{array}{l}\text { Total GHG } \\
\text { emissions }\end{array}$ & 0.152 & $3.116^{* * *}$ & 1.10 & & & \\
\hline $\begin{array}{l}\text { GHG } \\
\text { emissions } \\
\text { intensity }\end{array}$ & & & & 0.111 & $1.850^{*}$ & 1.09 \\
\hline ROA & -0.298 & $-3.630 * * *$ & 1.47 & -0.311 & $-3.621 * * *$ & 1.46 \\
\hline SIZE & -0.148 & $-2.241 * *$ & 1.49 & -0.163 & $-2.528 * *$ & 1.36 \\
\hline LEV & 0.159 & $2.616 * * *$ & 1.15 & 0.150 & $2.373 * *$ & 1.11 \\
\hline $\mathrm{M} / \mathrm{B}$ & -0.143 & $-2.116^{* *}$ & 1.54 & -0.143 & $-2.028 * *$ & 1.55 \\
\hline VOL & -0.238 & $-3.425 * * *$ & 1.63 & -0.268 & $-4.429 * * *$ & 1.44 \\
\hline Sector effect & \multicolumn{3}{|c|}{ Yes } & \multicolumn{3}{|c|}{ Yes } \\
\hline Year effect & \multicolumn{3}{|c|}{ Yes } & \multicolumn{3}{|c|}{ Yes } \\
\hline Adj. $R^{2}$ & \multirow{2}{*}{\multicolumn{3}{|c|}{$\begin{array}{l}0.210 \\
11.285^{* * *}\end{array}$}} & \multirow{2}{*}{\multicolumn{3}{|c|}{ 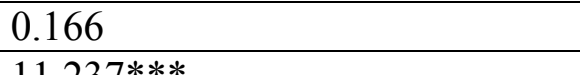 }} \\
\hline$F$-test & & & & & & \\
\hline $\mathrm{N}$ & \multicolumn{3}{|l|}{318} & & & \\
\hline
\end{tabular}

Notes: Please see Appendix for variable definitions. All t-statistics are corrected using the Huber-White procedure. $* * *, * *,{ }^{*}$ Significant at 1,5 and 10 per cent level, respectively. 


\section{Appendix: Variable definitions}

\begin{tabular}{|c|c|}
\hline Variables & Definitions \\
\hline $\mathrm{CoD}_{\text {it }}$ & $\begin{array}{l}\text { The cost of debt for firm } i \text { in year } t \text { is measured as following: } \\
\mathrm{CoD}=[[(\mathrm{SD} / \mathrm{TD}) *(\mathrm{CS} * \mathrm{AF})]+[(\mathrm{LD} / \mathrm{TD}) *(\mathrm{CL} * \mathrm{AF})]] *[1-\mathrm{TR}] \\
\text { Where: } \mathrm{SD}=\mathrm{Short} \text { term debt, TD }=\text { Total debt, } \mathrm{CS}=\text { Pre-tax cost of } \\
\text { short term debt, } \mathrm{AF}=\mathrm{Debt} \text { adjustment factor, } \mathrm{LD}=\text { Long term debt, } \\
\mathrm{CL}=\text { Pre-tax cost of long term debt, and TR = Effective tax rate. }\end{array}$ \\
\hline $\mathrm{GHG}_{\text {it }}$ & $\begin{array}{l}\text { Total GHG emissions (in metric tons) of firm } i \text { in year } t \text { are } \\
\text { measured as the total of direct emissions from GHG sources owned } \\
\text { or controlled by the firm (Scope 1) and indirect emissions caused by } \\
\text { the firm's consumption of electricity, heat or steam (Scope } 2 \text { ). }\end{array}$ \\
\hline & $\begin{array}{l}\text { GHG emissions intensity of firm } i \text { in year } t \text { is measured as the ratio } \\
\text { of total GHG emissions to total sales. }\end{array}$ \\
\hline $\mathrm{ROA}_{\text {it }}$ & $\begin{array}{l}\text { Return on assets measured as net income/total assets of firm } i \text { at the } \\
\text { end of year } t\end{array}$ \\
\hline $\mathrm{SIZE}_{\text {it }}$ & $\begin{array}{l}\text { Size measured by logarithm of total assets of firm } i \text { at the end of } \\
\text { year } t\end{array}$ \\
\hline $\mathrm{LEV}_{\text {it }}$ & $\begin{array}{l}\text { Leverage measured as total debt/total assets of firm } i \text { at the end of } \\
\text { year } t\end{array}$ \\
\hline $\mathrm{M} / \mathrm{B}_{\mathrm{it}}$ & $\begin{array}{l}\text { Market to book value measured by the ratio between market value } \\
\text { and book value of equity of firm } i \text { at the end of year }\end{array}$ \\
\hline $\mathrm{VOL}_{\mathrm{it}}$ & $\begin{array}{l}\text { Volatility measured by the standard deviation of the monthly stock } \\
\text { returns of firm } i \text { in year } t\end{array}$ \\
\hline SECT & $\begin{array}{l}\text { Sector fixed effect. The sectors are: consumer discretionary, } \\
\text { consumer staples, energy, financials, industrials, IT, materials, } \\
\text { telecommunications services and utilities. }\end{array}$ \\
\hline YEAR & Year fixed effect. The years are: 2012, 2013, 2014 and 2015. \\
\hline
\end{tabular}


Figure 1: Emissions per Capita for Top 10 Emitters

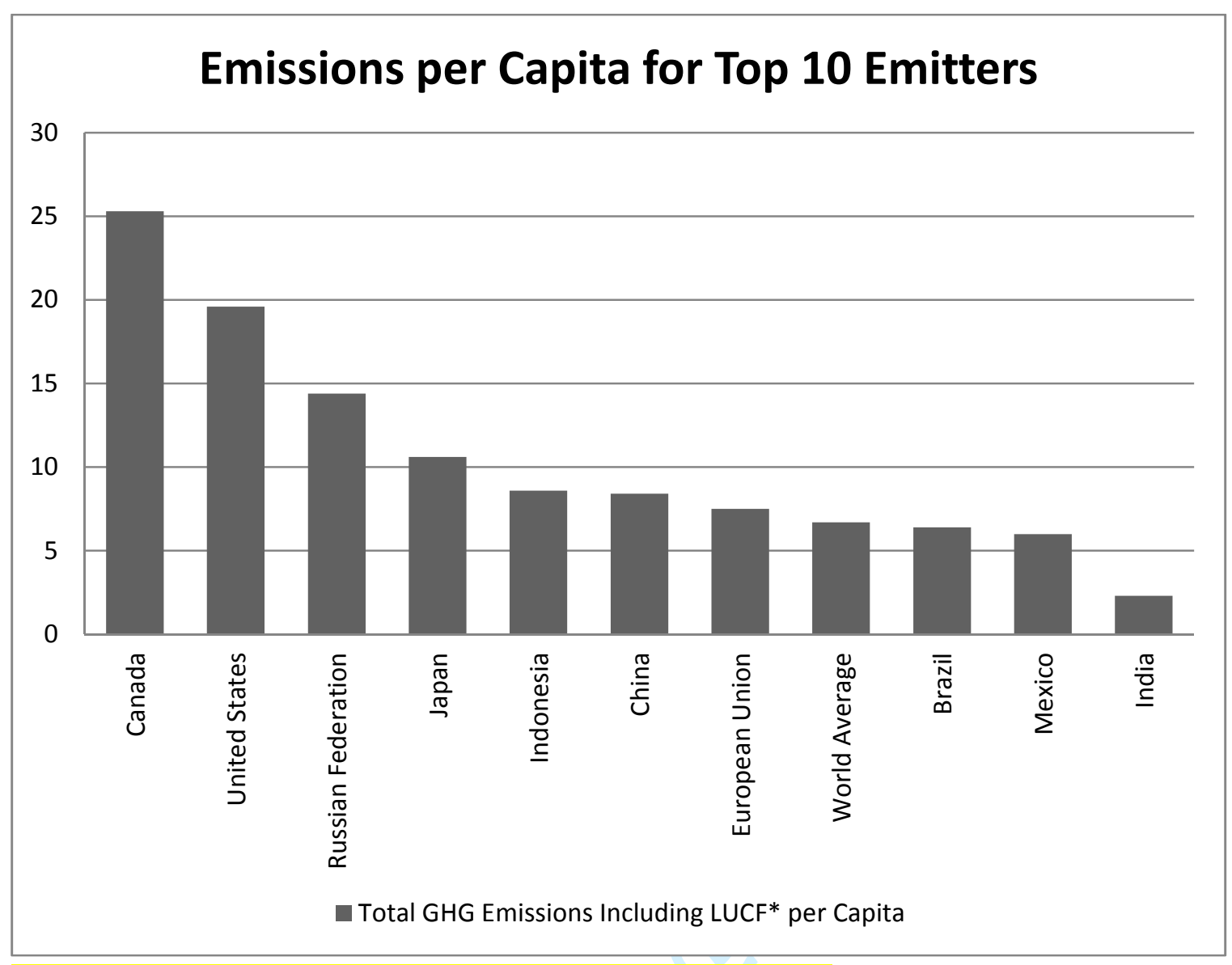

*LUCF refers to emissions stemming from land-use change and forestry.

Source: Adapted from World Resources Institute (2017) and CTV News (2017) 